\title{
The SCOTtish Educational CRISIS Of 2000: An ANALYsis of the Policy PROCESS OF UNIFICATION
}

\author{
David Raffe, Cathy Howieson, Teresa Tinklin \\ Centre for Educational Sociology, University of Edinburgh
}

\section{ABSTRACT}

The 'exam results debacle' of August 2000 provoked a crisis of confidence in Scottish education, and appeared to reveal widespread discontent with the current Higher Still reform of post-16 education. For a time the political future of the reform seemed to hang in the balance. This is surprising because the reform incorporated the views of the consensus that emerged from the Howie debates of the early 1990s, and its development involved consultation on a wide scale. Subsequent debates blamed the leadership style of those, especially the Inspectorate, who steered the reform process; some commentators invoked Humes' (1986) analysis of the 'leadership class' of Scottish education. This paper argues that a full explanation must take account of Higher Still's character as a flexible, unified system. Compared with other types of reform, the introduction of a flexible unified system tends to involve more conflict between educational interests, and a policy process that is relatively centralised, 'top-down' and linear. An analysis of this process must take account of horizontal as well as vertical lines of conflict in education, and of the political weaknesses which prevented the leadership from articulating clear principles and priorities as a basis for conflict resolution. The paper concludes that Humes' analysis should be complemented by McPherson and Raab's (1988) account of Scottish educational policy-making as the interplay of pluralist and corporatist forces.

\section{INTRODUCTION}

In August 2000 many candidates for Scottish Qualifications Authority (SQA) awards received results that were incomplete or inaccurate, or did not get them on time. The episode created a crisis of confidence for Scottish education, and it dominated the media for weeks. It was 'the biggest failure, and threat to the credibility, of the Scottish education system in living memory' (ELLC 2000, para 1). It seemed to call into question the Higher Still reform which aimed to bring post-16 school and college education into a unified curriculum and assessment system. The results that were due to be issued in August 2000 included the first wave of the new Higher Still awards, and the increased burden of data management associated with the new qualifications contributed to the SQA's failure. The 'exam results debacle' appeared to reveal widespread discontent with Higher Still, or with particular aspects of it, and for a while its political future seemed to hang in the balance. 
In this paper we aim to explain, not the exam results debacle itself, but the political crisis to which it gave rise. For the extent of this crisis, and the strength of discontent with Higher Still that it appeared to reveal, are surprising in view of the consensus from which the reform had sprung. It was a product of the consensus that emerged during the 'Howie debates' on Scottish post-compulsory education of the early 1990s, and it incorporated the main principles of that consensus: that the existing system needed to change, that a track-based system was unacceptable and that a flexible structure of courses should be retained. The subsequent development programme involved the largest consultation in Scottish educational history. Implementation was repeatedly re-scheduled to give more time. Thus, when they were first announced the reforms appeared to reflect a consensus among Scottish educationists, who continued to be consulted during the process of development and implementation. So what happened to the consensus on Higher Still? Why did the exam results debacle lead to such a political crisis?

We should not exaggerate the collapse of the consensus. Studies in the autumn and winter of 2000-01 showed continued support for Higher Still among a majority of staff in schools and colleges (ADES/ASC/HMI 2001, MORI 2001, Tinklin et al. 2001). Nevertheless the same studies, and much of the evidence submitted to the two committees of the Scottish Parliament which investigated the exam results debacle, revealed criticism of features of the Higher Still model that was introduced, of the speed with which it was implemented, and of the leadership style of those in the Scottish Executive, the Schools Inspectorate and their agencies who designed the reform and carried it through.

The political crisis of autumn 2000 also reflected more general dissatisfaction with current trends in the governance of Scottish education. The traditional policy leadership had reasserted its authority after an interval between 1987 and 1992 when it had been challenged by a right-wing minister, Michael Forsyth (Humes 1995). Its style of governance was increasingly managerialist, reflected in stronger mechanisms of accountability, target-setting, outcome-based controls and a growing propensity to prescribe methods of teaching (Fairley and Paterson 1995, Humes 1998). Teachers were seen as an ageing, conservative group, resistant to radical change; their professionalism was eroded and they were subjected to a 'blame culture' which Sam Galbraith, education minister in the Scottish Executive, and the Schools Inspectorate appeared to promote. The Inspectorate played a dual role as educational policy-makers and as the body which evaluated its own policies in practice. This, its critics argued, meant that the teachers rather than faulty policies were blamed when things went wrong. Many criticisms of the educational leadership expressed during the crisis of autumn 2000 recalled Humes' (1986) analysis of a small and cohesive 'leadership class' which manipulates the policy process in pursuit of its own interests. As one of the critics argued: 'Never before has Professor Walter Humes' term [the leadership class] seemed so apt. Whatever may be said for the more benign description of Scottish policy-making as being shaped by a policy "community", the centrally driven character of the Higher Still reforms seems to demand the much tighter description of a policy that was devised and implemented by people who were accustomed to exercising a leadership that was never seriously challenged. The inspectorate, above all, has been in charge of the policy throughout.' (Paterson 2000, p.172)

The establishment of the Scottish Parliament in July 1999 had provided the context in which dissatisfaction with the leadership could have political impact. It stimulated debates about the 
future governance of Scottish education. It undermined the claim to legitimacy of the Scottish Office, and especially the Inspectorate, as the champions of Scottish interests against a UK political leadership. It provided a forum in which grievances could be expressed, as the wellpublicised committee hearings during autumn 2000 were to show. And it subjected the leadership to much more effective democratic accountability than had ever been possible under the Westminster Parliament. The crisis had an impact. In October 2000 Galbraith was moved to the environment portfolio. In November his successor, Jack McConnell, announced that the Inspectorate would lose its policy-making powers. New arrangements for steering the Higher Still reforms ensured a strategic role for the main stakeholders.

One explanation, therefore, of the political crisis of Scottish education is that it released longsuppressed frustration and resentment of the style of governance of Scottish education. The leadership class of Scottish education had finally over-reached itself; the Scottish Parliament provided a new opportunity to call it to account, and its many critics rushed to its attack. However in this paper we argue that a full explanation must also take account of 'horizontal' as well as 'vertical' conflicts within Scottish education, and of the limitations on the power of the leadership itself. It needs to re-visit another classic analysis of Scottish educational governance, McPherson and Raab's (1988) analysis of the balance of pluralism and corporatism in the making of Scottish education policy. And it must refer to the distinctive nature of the policy being introduced. The policy process of introducing a unified system, and especially a flexible unified system, is different from the policy process of introducing other types of educational reform. It is associated with stronger and more visible conflicts both between the different sectors and interests within education and between the leadership and the rest of the system.

Our analysis draws on two ESRC-funded research projects, one on the development of Higher Still and the other on its introduction, and it builds on an analysis in an earlier paper (Raffe and Howieson 1998). In the next section we outline the chronology of events since 1990. In the following section we analyse the policy process of Higher Still through seven propositions which explain why a seemingly consensual reform process came to generate such political controversy. In the final section we discuss our conclusions in relation to McPherson and Raab's analysis.

\section{THE History OF Higher STILL: A BRIEF OVERVIEW}

\section{The Howie Committee}

In 1990 a committee chaired by Professor John Howie was appointed to review courses, assessment and certification in the fifth and sixth years (S5 and S6) of Scottish secondary schools - the two post-compulsory years. The main components of the current system were subject-based courses for the Higher grade of the Scottish Certificate of Education (SCE), notionally of 120 hours, and National Certificate (NC) modules, notionally of 40 hours. Highers tended to be in academic subjects, were delivered through a relatively traditional pedagogy, and were mainly assessed by external examinations. Modules were more vocational, at least in the sense of placing more emphasis on competence; their pedagogy was more student-centred and their assessment internal. Highers were usually completed within a 
single year although there was a trend for weaker students to take some Highers over two years, sometimes using modules as a bridge. Students with good Standard grade results from fourth year (S4) typically took five Highers in S5 followed by repeated or new Highers and/or Certificate of Sixth Year Studies (CSYS) in S6. CSYS were subject-based courses designed for students who had passed Higher and planned to progress to university. However most students, and especially those with poorer Standard grade attainments, mixed Highers and modules in varying combinations. Staying-on rates were rising fast among 16 year olds, with the result that schools had to cater for an increasingly wide ability range at 16-plus. In contrast with other parts of the UK, relatively few young people transferred from school to Further Education (FE) colleges at 16. Most of those who did so took programmes of NC modules.

This system was seen to be failing less able and able students alike. Students entering S5 with poor Standard grade results had to choose between low-status modules, often offered in an arbitrary range of subjects depending on school staffing and resources, and Highers which offered a high risk of failure. Often they mixed the two, and had to cope with their different pedagogies and styles of assessment. Better-qualified students took Highers courses which lacked breadth and depth compared to other European qualifications. The short Highers courses led to over-examination and stress and inhibited deeper learning. Some commentators advocated a two-year Higher, but others feared that this would anglicise the Scottish system, discourage participation and reduce flexibility. It was also resisted by the universities which feared that it would undermine the case for maintaining a four-year Honours degree, longer than elsewhere in the UK. As a result, much of the evidence to the Howie Committee stressed the virtues of the existing arrangements, and especially the flexibility of course structure and pathways. The ability to take decisions year-on-year, it was argued, encouraged higher participation than elsewhere in the UK and sustained a broader curriculum with weaker boundaries between academic and vocational learning. Any change should be evolutionary and incremental.

The Howie Committee reported in 1992 (SOED 1992). It rejected both the caution of these submissions and their support for flexibility. It confirmed the more critical diagnoses of the existing system: standards for the higher attainers were too low, and 16 year olds with low Standard grade results who stayed on at school were exposed to an incoherent curriculum and high failure rates. It diagnosed an 'uneven gradient of difficulty' in secondary education, too shallow in the early years, too steep for many students in later years. It therefore proposed to advance Standard grade to third year (S3), so that upper-secondary education could last up to three years, starting at age 15. This would be based around two tracks. The upper track, modelled on the current Danish system, would cater for $35-40 \%$ of the age group in two principal lines, arts and science, followed over three years. The lower track would be modular, last one or two years, and be available in colleges as well as schools.

The Howie Report radicalised the debate about upper-secondary education. The question was no longer whether reform was needed, but what kind of reform. However, Howie's proposal for a twin-track system was almost unanimously rejected in the consultation that followed (McPherson 1992). There was also resistance to curriculum models which might restrict choice or create barriers to attainment and progression by requiring particular subjects such as mathematics and foreign languages. In 1993 the initiative passed back to the Inspectorate, which had played a leading role in setting up the Howie Committee and in shaping its agenda. 
It now had the task of devising a reform which addressed the various problems identified by Howie but which retained curriculum flexibility and avoided tracking. By the end of 1993 it had developed, and won support within the Scottish Office, for a model based on group awards at five levels. Each group award would typically be covered over a year's study, and would be specified in terms of the volume and level of credit, and attainment in core skills. This model would have retained substantial curriculum flexibility subject to the group award being the main unit of currency. However it would have abolished the position of the Higher as the main currency of the curriculum. Not only was the Higher a symbol of the Scottish educational tradition, but it had also been identified, in the Howie debates, with the flexibility of Scottish education and its perceived benefits for participation and breadth. This was too much for the Secretary of State, Ian Lang, who rejected a system based on group awards.

\section{The Higher Still framework}

The proposals that were eventually published, in March 1994, incorporated many features of this earlier plan but without the central role of group awards. Higher Still: Opportunity for All (Scottish Office 1994) proposed a 'unified curriculum and assessment system' based on provision at five levels, subsequently named Access, Intermediate 1, Intermediate 2, Higher and Advanced Higher. The system was to cover academic and vocational provision for all ages from 16 upwards in schools and colleges, and for all levels below higher education. The main qualifications not covered would be Scottish Vocational Qualifications (SVQs), which were occupationally specific and designed (at least in principle) for workplace delivery. The new unified system would have a single set of design rules for curriculum, assessment and certification. Its basic architecture comprised 40-hour units and 160-hour courses. A course comprised three units plus a further 40 hours' worth of induction, remediation, integration and assessment; units could also be free-standing or delivered in programmes not based on courses. Units would be internally assessed (primarily using 'NABs' drawn from a National Assessment Bank); courses would be externally assessed, typically through written examinations or project work. Courses and units could also be combined into what came to be labelled Scottish Group Awards (SGAs), achievable within one year's full-time study. General SGAs were specified in terms of the level and volume of study and the attainment of core skills.

The new framework was designed to map on to the existing system (see figure 1). Units corresponded to existing modules. Courses corresponded to existing SCE (Highers and CSYS) courses, but with more study time, and with new courses in vocational subjects and at levels below Higher. SGAs corresponded to General SVQs (programmes of modules) which had been introduced in colleges and some schools in 1992. The new Higher level corresponded to the existing Higher, and the new Advanced Higher corresponded to CSYS. Intermediate 1 and 2 were benchmarked against levels of Standard grade attainment, and were similar to the level of much current modular provision. It was proposed that the new system would be developed incrementally from the old one. Indeed Opportunity for All listed the 'expansion and rationalisation of existing provision' and the 'consolidation of earlier reforms' among the aims of the reform. Implementation was initially scheduled for 1997, but this was soon put back to 1998. After the 1997 General Election it was deferred again, to 1999. 
Figure 1. Design rules of the old and new systems : a summary

\begin{tabular}{|c|c|c|c|}
\hline & Old s. & tem & Higher Still (National Qualifications) \\
\hline \multirow{3}{*}{$\begin{array}{l}\text { Units of } \\
\text { curriculum and } \\
\text { certification }\end{array}$} & SCE: & COURSES (notionally 120 hours) & \multirow{2}{*}{$\begin{array}{l}\text { UNITS ( } 40 \text { hours) } \\
\text { which may be grouped into } \\
\text { COURSES ( } 160 \text { hours, } 3 \text { units plus } \\
\text { additional credit for external assessment } \\
\text { etc) or CLUSTERS ( } 3 \text { units) }\end{array}$} \\
\hline & \multirow[t]{2}{*}{$N C:$} & $\begin{array}{l}\text { MODULES (notionally } 40 \text { hours) } \\
\text { which may be grouped into } \\
\text { GROUP AWARDS (GSVQs: 12-18 } \\
\text { modules) }\end{array}$ & \\
\hline & & $\begin{array}{l}\text { or } \\
\text { OTHER PROGRAMMES (e.g. college- } \\
\text { devised) }\end{array}$ & $\begin{array}{l}\text { Units and Courses/Clusters may be } \\
\text { grouped into } \\
\text { SCOTTISH GROUP AWARDS (12-20 } \\
\text { credits) }\end{array}$ \\
\hline \multirow[t]{2}{*}{ Levels } & SCE: & 2 LEVELS (Higher and CSYS) & \multirow{2}{*}{$\begin{array}{l}5 \text { LEVELS (Access, Intermediate 1, } \\
\text { Intermediate 2, Higher, Advanced Higher) }\end{array}$} \\
\hline & NC: & $\begin{array}{l}\text { NO GENERAL FRAMEWORK OF } \\
\text { LEVELS: covers all levels up to and } \\
\text { including Higher }\end{array}$ & \\
\hline \multirow[t]{2}{*}{ Subjects } & SCE: & MAINLY 'ACADEMIC' & \multirow[t]{2}{*}{ ACADEMIC AND VOCATIONAL } \\
\hline & $N C:$ & VOCATIONAL AND GENERAL & \\
\hline \multirow[t]{2}{*}{ Core skills } & SCE: & NOT REQUIRED & \multirow{2}{*}{$\begin{array}{l}\text { EMBEDDED across the curriculum where } \\
\text { appropriate } \\
\text { REQUIRED FOR SGAs }\end{array}$} \\
\hline & NC: & $\begin{array}{l}\text { REQUIRED FOR GSVQs (Group } \\
\text { awards) }\end{array}$ & \\
\hline \multirow[t]{3}{*}{ Assessment } & SCE: & MAINLY EXTERNAL (examinations) & Units: INTERNAL (using NABs) \\
\hline & \multirow[t]{2}{*}{$N C:$} & INTERNAL & $\begin{array}{l}\text { Clusters: INTERNAL (for constituent } \\
\text { units) }\end{array}$ \\
\hline & & & $\begin{array}{l}\text { Courses/SGAs: INTERNAL (for } \\
\text { constituent units) AND EXTERNAL } \\
\text { (examination or project) }\end{array}$ \\
\hline
\end{tabular}

\section{Development and implementation}

In 1994 the Higher Still Development Programme was launched. It was led by the Higher Still Development Unit, which was located within the Scottish Consultative Council on the Curriculum (SCCC) but reported directly to the administration and the Inspectorate within the Scottish Office. The HSDU was led by a Chief Development Officer and staffed by Development Officers seconded from schools and colleges for varying lengths of time. Inspectors played a prominent and visible role in the development process and in the consultations. The programme was steered by a Strategy Group, on which many of the main interests and organisations involved were represented, with the Senior Chief Inspector as chair. The Strategy Group was itself supported by three task groups, on curriculum and assessment, staff development, and information and publicity. In 1995, 1996 and 1997 there were consultations based on a series of documents published by the HSDU. These covered such issues as the principles for the curriculum, nomenclature, guidance, special educational needs, Access level provision, SGAs, core skills, and curriculum guidelines for schools and colleges, as well as 'frameworks' for each subject. However, as the Association of Directors of Education in Scotland (ADES) later pointed out, no consultation paper was issued on assessment and reporting: 'the major debate which should have taken place not merely on the principles of the new assessment regime but on its practical operation failed to materialise' (ECSC 2000b, p.426). The HSDU published a document on assessment in May 1996 but this 
was 'for information only' (HSDU 1996a). The consultations were supported by seminars and other events attended mainly by the senior and middle management of schools and colleges.

In 1997 the Strategy Group was replaced by an Implementation Group, also chaired by the Senior Chief Inspector, with similar participation but more local authority representation. It was supported by sector groups representing schools, further and higher education and employment and training interests. However, as at earlier stages of the process, committees tended to proliferate, and working groups and committees of varying formality and longevity took over much of the decision-making from the groups that were formally responsible. The most important example of this occurred at the end of 1998, when the Educational Institute of Scotland (EIS), the main teachers' union, threatened to boycott the implementation of Higher Still. A Liaison Group, representing the main stakeholders, was set up to deal with the problem. It brokered a deal whereby the first phase of implementation would proceed in 1999, but a slower phasing in was negotiated for particular subjects on a school-by-school basis. The Liaison Group thus proved its political value and it informally became the main strategic body overseeing the implementation.

Implementation was scheduled over a five-year period beginning in 1999. The arrangements for phasing the introduction of Higher Still courses gave priority to the 'phase 1' Highers which replaced existing SCE Higher courses; 'phase 2' Highers in new (typically vocational) subjects, and provision at other levels such as Intermediate 1 and 2, had lower priority. The rationale for this order of implementation was that it enabled teachers to become familiar with the new arrangements through incremental steps. The curricula of most phase 1 Higher subjects were similar to the SCE Highers that they replaced, so they provided an opportunity for teachers to become familiar with the new features of the system, such as the assessement arrangements, without having to cope with radically new curricula at the same time. There was also a more pragmatic rationale: the production of information and materials for phase 2 Highers, and indeed for many other Higher Still courses and units, had fallen well behind schedule.

The first year of implementation affected schools much more than colleges, some of which offered little or no Higher Still provision in the first year. A majority of former SCE Highers were replaced by the new Higher courses, with the exception of subjects (especially English and Communication, Art and Design and Chemistry) where a slower phasing had been agreed by the Liaison Group in some schools. There was an unexpectedly large take-up of the new Intermediate 1 and 2 courses. This reflected schools' support for one of main aims of Higher Still, to improve provision and progression opportunities for middle-and lower-attaining 16 year-olds who stayed on at school. Most provision in the first year comprised courses rather than stand-alone units. About two-thirds of FE colleges offered SGAs, but most offered just one or two, as a means of gaining experience of the new system (SFEU/HSDU 2000).

\section{The exam results debacle}

The new system was administered by the SQA, which had been established in 1997 by the merger of the Scottish Examinations Board (SEB), the body responsible for academic SCE awards, and Scotvec, the body responsible for $\mathrm{NC}$ and other vocational qualifications. The merger had been contemplated for several years, but the unified system of Higher Still was the immediate trigger (Spours et al. 1998). For the first two years the SQA administered the 
former SEB and Scotvec qualifications through separate systems. The introduction of a unified qualification system in 1999 made it necessary to introduce unified arrangements for managing the various procedures involved in registering candidates, recording internal assessments, arranging external assessments, recording their results, and issuing certificates. These arrangements failed. During the 1999-2000 session problems with the flow of information between presenting centres (schools and colleges) and the SQA became evident. A backlog of unprocessed data accumulated. By summer 2000 newspaper articles began to mention 'computer problems' that might delay the issuing of results. On 9 August, when the results were due to be posted, the SQA announced that all certificates would be issued on time but that about $1 \%$ of certificates would be affected by incomplete data. In the event only 137,000 of the 147,000 candidates received their certificates on the right day, and 18,232 courses were affected by missing or incomplete data. These represented only $2.7 \%$ of all courses, but most candidates were presented for several courses and one in nine of all candidates were affected (Scottish Executive 2000, paras 3.2.3-4). Some of these candidates received inaccurate results, for example being awarded fail grades because the system had not recorded one of the internal assessments which were required for a pass. An extended appeals process lasted well into 2001.

The exam results debacle affected other awards as well as Higher Still awards, but the data requirements of Higher Still were an important contributory factor. The volume of data to be handled was considerably larger than under the previous system, as candidates needed to register for each unit as well as each course, and the award of a certificate depended on the results of internal unit assessments as well as the external assessment. The SQA's ability to meet these increased demands was obstructed by the need to design and introduce a new computer system in a very short period with little opportunity for testing; by the later scheduling of exams which reduced the time for marking and processing the results; by schools' and colleges' unfamiliarity with the new system; by a re-designed form; by the demands of a new cumulative certificate which listed all SQA awards to date as well as a core skills profile; by the failure to recruit sufficient markers for the examinations; by the late supply of information; and by numerous lapses of communication. The subsequent inquiries blamed the problems primarily on the SQA's management, which failed to appreciate the scale of the task, to give it sufficient priority or to establish appropriate procedures for steering and monitoring it. The Parliament's Education Committee blamed 'an assumption by the Senior Management Team that because there had never been a previous failure in the operations side of the examination, and because SQA had run the [pre-existing] systems successfully, this side of the business would look after itself" (ECSC 2000a para 121).

The Chief Executive of the SQA, Ron Tuck, resigned on 12 August. The political crisis that followed the exam results debacle lasted for several weeks, with intense media coverage and extravagant speculations concerning the scale and consequences of the debacle. There were attacks on the Inspectorate and repeated calls for the resignation of Sam Galbraith, Minister of Education in the Scottish Executive. This was in spite of the fact that responsibility for the operations of the SQA lay not with Galbraith but with Henry McLeish, Minister of Enterprise and Lifelong Learning. Galbraith had lead responsibility for Higher Still and much of the debate focused on the implementation of Higher Still rather than on narrower operational issues. 
Two committees of the Scottish Parliament held inquiries into the crisis: the Enterprise and Lifelong Learning Committee focused on the governance of the SQA; the Education Culture and Sport Committee had a somewhat wider remit, which included the effect of the implementation of Higher Still and the role of the Executive and its relationship with the SQA. Many submissions to the two committees criticised the implementation of Higher Still. Its model was seen as too complex and 'over-engineered', and to make too many demands on teachers and others who had to put it into practice. The emphasis on core skills, the design of the certificate, and above all the volume and organisation of internal assessment came under attack. There were some challenges to the more fundamental principles of Higher Still, including its aim to unify academic and vocational curricula. It was claimed that the reforms were introduced too quickly, that information, materials and assessment instruments were not available in time, and that teachers had too little time in which to prepare. The Scottish Executive (and before it the Scottish Office) and the Schools Inspectorate were accused of driving the reform through in an arrogant and unresponsive manner and of ignoring warnings that things were not going well.

The Enterprise and Lifelong Learning Committee concluded that the SQA's failure 'occurred at an operational level within the organisation, below the level of governance, and was not communicated upwards' (ELLC 2000, para 38). Both Committees largely absolved the Scottish Executive from blame, although they criticised some aspects of its role. However, the Education Committee was less restrained in its comments on the Inspectorate: 'So many sectors of the Scottish educational community voiced their concern to the Committee that there was a conflict in the role of the Inspectorate as controllers of the Higher Still Development and evaluators of its success that it is essential that their role be redefined.... [E]ducational developments should no longer be under the control of HMI. They should act solely as the quality assurance agents for such developments' (ECSC 2000a, paras 265-6). The Committee expressed support for the direction of educational change represented by Higher Still but proposed that assessment arrangements should be simplified. The First Minister, Donald Dewar, resisted the numerous calls for Galbraith's resignation, but at the ministerial reshuffle following Dewar's death Galbraith was moved to the environment department. Within weeks of taking office his successor, Jack McConnell, announced that the HMI would lose its policy-making powers and become an Executive Agency. A National Qualifications Steering Group (NQSG) was established late in 2000, giving the main stakeholders a continuing input into the strategic policy issues of the future direction of Higher Still.

In 2001 policy attention focused on avoiding a repetition of the previous year's debacle, and on simplifications to the Higher Still model in the longer term. In June McConnell announced his intention to reduce internal assessment, following a report by the NQSG (Scottish Executive 2001), although this provoked opposition from college interests, who warned against re-introducing a two-track system with schools offering externally assessed courses and colleges offering internally assessed units (TES Scotland 15 June 2001). One consequence of the crisis was a slower pace and narrower scale of implementation: in the winter of 2000-01 a third of schools and colleges said that the SQA's problems had affected their own plans for Higher Still (Tinklin et al. 2001). Nevertheless, despite the crisis, most of the main stakeholders had reaffirmed their support for the basic principles of Higher Still. 


\section{EXPLAINING THE CRISIS OF AUTUMN 2000}

In this section we attempt to explain why the exam results debacle had such a political fallout, and how it represented more than the release of suppressed resentment of the 'leadership class' of Scottish education. To do this we analyse the policy process of the development and introduction of Higher Still. We express our argument in terms of seven propositions.

\section{The model of post-compulsory education introduced by Higher Still is a flexible unified system}

The unification of post-16 education is the trend, common to most countries, for different tracks to be brought closer together into a 'linked system' or to be integrated within a single 'unified system'. It is a product of the expansion and the growing functional complexity of post-compulsory education, and the resulting pressure for greater coherence and coordination; but the aims, strategies and consequences of unification vary across countries (Raffe et al. 1998, Young et al. 1998). In Scotland many of the weaknesses of the previous system arose from differences in the content, teaching, assessment and certification of SCE and Scotvec provision and from the inadequacy of progression routes. These differences contributed to incoherent curricula, status differences, a lack of transparency and barriers to participation and progression, especially for middle- and lower-attaining students (Howieson et al. 1990, Raffe 1997). Higher Still aimed to resolve these weaknesses by bringing different types and levels of provision into a unified system with common design rules. The unified system embraces

- different types of curricula (academic and vocational),

- different levels of study (from Access to Advanced Higher),

- different institutions (schools and colleges) and

- different age groups from 16 upwards.

Unification was the logical outcome of the post-Howie consensus that existing provision needed to be made more coherent but that a track-based system was unacceptable. However as we see below the concept of unification, let alone Higher Still's specific model of a unified system, was rarely made explicit in the debates that followed Howie.

There was a more explicit endorsement of the flexibility of subject choice and student pathways found in the existing system. This was believed to encourage participation and breadth of study. Flexibility also suited the prevailing market philosophy and the emerging lifelong learning agenda, and the political reluctance to abolish or downgrade the Higher. Higher Still is a flexible unified system. It has flexible entry and exit points and the volume, content and level of study are open. It contrasts with Baccalaureate or programme-based models of unified systems where the levels of entry and of leaving, and much of the content of the programme, are more strongly prescribed.

\section{Designing and introducing a unified system is a more conflictual process than designing and introducing most other types of reform}

As a unified system Higher Still applies common design principles to different types of curricula, institutions, levels of study and age groups. These four divisions often emerged as lines of conflict during the development of Higher Still; the sectors or types of provision 
defined by these 'fault lines' had different interests in the design rules of a unified system. For example, schools and colleges expressed different interests in such matters as the grading of awards or the role and design of SGAs (Howieson et al. 1998). There were different interests in assessment: those responsible for lower levels of study and for the education of adults were concerned about the demotivating effect of external assessment, while interests associated with higher-level academic courses for young people voiced concerns about an increased role of internal assessment. There were different interests in the curriculum, the most vociferous of which was a group of teachers who resisted the attempt to combine academic and vocational purposes in the English curriculum (SATOLL 1999).

Any system-wide policy change is likely to involve conflicts of this kind. However, most policy reforms (such as 'linkages' strategies for unification) can resolve them either by exempting parts of the system from the common design rules or by allowing the design rules to vary. A unified system, on the other hand, permits neither exemptions nor variations. So, not only is a policy for a unified system likely to face conflicts, but it is much harder to resolve these conflicts in the process of policy development and consultation.

\section{Designing and introducing a flexible unified system is more conflictual than for other kinds of unified system}

Such conflicts are likely to be sharper, and more difficult to resolve, if the unified system being introduced is a flexible one. In a Baccalureate model of a unified system the certificate for the whole programme, the Baccalaureate itself, is the main currency. This might have been the case for Higher Still had the earlier proposals based on group awards been accepted. However, in the model that was developed the currency came in much smaller denominations, in the form of courses and units. The common design principles therefore had to apply at the level of courses and units; they were consequently much more pervasive and the conflicts much deeper. Moreover, a system which allowed flexible accumulation and transfer of units as well as courses required a large volume of assessment, since each unit and course had to be separately certificated. External assessment on this scale would have been impractical, so the model called for a large volume of internal assessment. This provided a further basis for conflict. As the earlier experience of modularisation in Scotland had demonstrated (Howieson 1992), the biggest problems faced by flexible educational structures tend to be associated with the increased demands and changed character of assessment.

The introduction of a flexible unified system, more than other types of reform, involves conflict which cannot easily be resolved through consultation. Other means of conflict resolution are therefore more important: in particular, an appeal to a prior consensus around the goals and principles of the reform. But had not a consensus already been achieved during the debate on the Howie Report?

\section{The scale of the reform and its underlying vision were under-sold}

The consensus that emerged after the Howie Report was a negative one: Scottish educationists agreed on what they did not want, and that was a twin-track system. Opportunity for All responded to this consensus by abandoning Howie's twin-track system, but it made little attempt to expound or promote the principles underlying the unified system which it offered instead. A unified system on the general lines of Higher Still may have been implicit in Scottish educationists' rejection of a twin-track approach, but it was not an explicit 
part of this consensus. Opportunity for All made no attempt to expound or promote the principles of a unified system, or indeed to explain why its strategy was the necessary consequence of a desire to reform post-16 education without introducing tracking. The logical leap from the post-Howie consensus to a unified system was assumed, not argued.

Indeed, far from selling a positive vision of a unified system, Opportunity for All presented it as a technical response to the problems identified by Howie. Its presentation was low-key. Rather than a radical new direction in post-16 education, Higher Still was presented as a technical fix which addressed specific problems and continued an incremental and evolutionary process of improvement. Incrementalism - the 'consolidation of earlier reforms' - was elevated to an Aim of Higher Still. This low-key approach continued through the development and consultation process. Even at a late stage in this process school and college staff were being told that Higher Still would represent 'business as usual', and that to begin with at least their involvement would be just 'a toe in the water' (Raffe and Howieson 1998).

The under-selling of Higher Still, and the failure to win support for its underlying vision and principles, had a number of serious consequences. A possible basis for conflict resolution - a shared vision of the principles of the reform - was lost. School and college staff were not prepared for the scale of the changes, and reacted more strongly when these turned out to be much larger than had been suggested. The perceptions of the reform among the public, and among many educationists, remained incomplete and partial: in autumn 2000 it was still widely perceived as a reform only of the SCE Higher, but divorced from the wider reforms the changes to the Higher had no convincing rationale. Finally, Scottish education ministers were not prepared for the scale of the changes, and consequently failed to recognise the need for political leadership on behalf of Higher Still until it was too late. This last consequence was compounded by the change of government in 1997 (politicians are reluctant to campaign for a previous administration's policies) and by the separation in 1999 of educational responsibilities between two departments of the Scottish Executive, with Higher Still split between them.

\section{The under-selling of Higher Still reflected, among other things, the weakness of the leadership}

Ironically, the under-selling of Higher Still reflected the limits to the power of the leadership, more than its arrogance. The leadership's power was limited, in the first place, by its dependence on the support of teachers and lecturers to implement the reform. Teachers were already complaining of innovation fatigue and of an excessive and growing workload; an admission that Higher Still was a major reform would invite resistance. It would also imply a commitment to spend large additional resources on development and implementation. It may have seemed politically wiser to defer any confrontation until the reform process had become embedded.

The leadership was, moreover, divided. Higher Still was mainly drafted by the Inspectorate, but it was introduced by Ian Lang as Secretary of State in a Conservative government. The proposals that were published in 1994 already represented a retreat from the Inspectorate's favoured position, as Lang had rejected key elements of its earlier plans such as the central role for group awards. It was harder to define a vision for a policy which had already been compromised. Moreover, the Inspectorate could not be too active in promoting a vision which 
contradicted Conservative policy elsewhere in the UK. The philosophy and general approach of Higher Still were similar to those of proposals for unification in England and Wales, which the government had resisted in its defence of the A level 'gold standard' (Richardson 1993). It was politically much easier to present Higher Still as a technical solution to recognised problems.

The leadership's power was further weakened by its inability to deploy a guiding ideology. Not only must it be guarded in using the rhetoric of unification, but there was no prospectus or blueprint for a flexible unified system on which it could draw. Existing proposals for unified systems, such as the British Baccalaureate (IPPR 1990) or the National Commission on Education's (1993) General Education Diploma, were Baccalaureate- or programmebased. In 1990 the John Wheatley Centre had attempted to develop a Scottish version of the British Baccalaureate, as an input to the Howie Committee, but this did not bear fruit.

In addition, the educational community may have become fatigued, not only by innovation, but also by debates about principles. The first round of Higher Still Consultation Documents invited discussion on principles for the post-16 curriculum and core skills; many respondents appeared impatient to move on to the detailed planning of the new arrangements, and complained that the documents lacked sufficient detail (HSDU 1996b, p.4).

\section{The process of introducing a unified system tends to be be linear, centralised and top- down, and to disenfranchise participants}

The process of developing a unified system involves constructing, testing and refining common design rules to be applied across the whole system. It requires tighter central coordination, to maintain the unity of the system and to resolve the conflicts described above. It also involves a more 'linear' separation of policy development and implementation. It is harder for policy to continue to develop locally during implementation, because any change that is made to meet the needs of a particular subject, mode or level of provision must be applied to the whole system. During the implementation phase some participants compared this phenomenon with the flapping of the butterfly's wing which causes a tempest on the other side of the globe.

In our earlier analysis we used the term 'democratic centralism' to describe the Higher Still development and consultation process. We reported that 'the desire to consult appeared genuine, within the limits of [the consultation's] focus on "technical" issues' (Raffe and Howieson 1998 p.99). However the process fell short even of democratic centralism to the extent that participants either lacked the information, or lacked the perspective and experience, with which to address the system-wide issues raised by a unified system. Most participants could express the views of their own sector, subject or level of study, but only those with a 'system-wide' perspective could form a view on how these different interests might be reconciled and aggregated within a national framework. Consequently only people or organisations with an institutionalised 'system-wide' perspective were fully enfranchised in this process. They included the Inspectorate, the SQA, and the HSDU, but they excluded most teachers and even most school heads and college principals. Consequently the consultation and development remained essentially 'top-down' processes. The disenfranchisement of many participants was exacerbated by the unreliable flow of 
information to, and within, schools and colleges, and by growing 'consultation fatigue': the number of responses to consultation documents dropped off over the course of the process.

Even participants in the formal committees which oversaw the reforms could be disenfranchised. There was a constant flux of committees and working groups, whose influence was often informal and which formed a shifting network with considerable crossmembership. Many decisions were not formally reported back, which meant that even those who were on the main strategic committees were poorly informed and lacked an overall perspective on progress. The Scottish Parliament's Education Committee noted 'the confusion, of which there was much evidence, arising from the plethora of organisations and committees involved in the development and implementation of Higher Still' (ECSC 2000a, para 251).

The style of implementation was not solely the result of the nature of the reform as a flexible unified system. The leaders of Higher Still were determined not to repeat the experience of the development of Standard grade in the 1980s, which involved wide grass-roots participation but at the cost of a slow and cumbersome process of change. The development of Higher Still was planned as a 'managed process'. It reflected the general trend towards managerialism, discussed earlier, as well as a degree of mistrust of the conservatism of teachers. Some leaders of the reform aimed to create a dynamic, flexible system that would be 'teacher-proof'.

The situation was aggravated due to an accident of timing. During the period of the Higher Still consultations the old education authorities were replaced by new unitary local authorities. The new authorities were smaller, were expected to have a less 'strategic' role, and were too new and preoccupied by their own transition process to have a large involvement in the consultation. As a result an important source of pluralism in the process was lost.

\section{Specific implementation decisions exacerbated some of these problems}

The consultation process was used to inform as well as to consult about the reforms. Early consultation events were targeted on senior managers in schools and colleges, and later events tended to be for heads of department or their equivalents. The intention was that those who participated directly in the consultations would exchange information with others in their institutions, whose views could thus feed in to the consultation process. Few unpromoted staff were directly involved in the consultations, and it was intended that their information needs should be met by activities within institutions or local authorities. This 'cascading' approach is perceived by participants on both sides of the process to have been unsatisfactory. Information did not always flow freely. Many participants at consultation seminars complained either that documents had not reached institutions or that they were not being distributed appropriately within them. The consultation had insufficient input from those at the 'chalkface' responsible for implementing the proposals. The cascading approach also contributed to the perception of Higher Still as a 'top-down' reform that was imposed on teachers.

The arrangements for phasing the introduction of Higher Still courses gave priority to the 'phase 1' Highers which replaced existing SCE Higher courses; provision at other levels, such as Intermediate 1 and 2, and 'phase 2' Highers in new subjects, had lower priority. This 
prioritisation did not follow the sequence of student progression, which would have involved starting with Access (or perhaps Intermediate 1) and working upwards, introducing a new level each year. It perpetuated the notion that Higher Still was all about Highers and that it tried to fix the part of the system that, seen in isolation, least needed fixing. It obscured the rationale of Higher Still as a means of promoting parity of esteem for academic and vocational courses, and of enhancing opportunities for the middle- and lower-attaining 16 year-olds. The biggest success of Higher Still in its first year was that schools offered more Intermediate 1 and 2 courses than expected, reflecting the priority that they placed on new provision at this level. An implementation strategy which reflected this priority might have won readier acceptance and better public understanding of the reform. Above all, a strategy which started by changing the SCE Higher was a high-risk strategy since it focused on a highstatus, highly visible symbol of the school system - the 'holy of holies of Scottish education' (Brunton, quoted in Gray et al. 1983, p.52). The exam results crisis would not have attracted nearly so much attention if the courses affected had merely been replacements for modules. Schools had been using internal assessment for modules and some Standard grades since the 1980s; only when it was extended to Highers did internal assessment attract much controversy or media attention.

\section{Discussion}

We have argued that the political crisis of Scottish education in autumn 2000 was more than a reaction to the style of the leadership of Scottish education. A full explanation must draw, not only on Humes' (1986) analysis of the leadership class, but also on another classic analysis of policy-making in Scottish education, McPherson and Raab's (1988) Governing Education. Four themes from that study are echoed in our analysis.

The first is the inadequacy of the traditional view of Scottish education as centralised. Had the Inspectorate been truly powerful it could have asserted, and gained support for, a clear and coherent vision of a unified system, which could have been the basis for resolving subsequent conflicts. Its leaders in the early 1990s were capable of articulating such a vision. But McPherson and Raab point out that the power of the centre has always been curtailed by the need actively to construct a consensus for its policies. The leadership's ability to articulate its vision of reform was constrained by fears of losing teacher support, or of precipitating conflicts between different educational interests. McPherson and Raab also argue that there has been no single centre of government of Scottish education: the Inspectorate could not actively promote a vision of unification without losing the support of civil servants and politicians; and its own proposals for reform were vetoed.

The second theme is the importance of horizontal as well as vertical conflicts within education, and the complex relationship between them. McPherson and Raab express this relationship in terms of the shifting balance of pluralism and corporatism in the policy process. The conflicts over Higher Still met at least one criterion of pluralism: they were substantially separate from civil society. The reform was largely driven by pressures and tensions internal to the education system, and external interests, notably those of employers, had relatively little influence (Spours et al. 2000). In other respects, however, the Higher Still policy process displays many of the corporatist features described by McPherson and Raab: the central coordination and management of the development; the selective and shifting 
incorporation of the leaders of key interest groups in the policy and development processes; the management of the policy agenda; and the relative disenfranchisement of practising teachers and lecturers.

The third theme is the way in which the policy process is changing as a result of the changed nature of the education system and of the content of policy. McPherson and Raab (1988, p.489) describe how educational expansion - in both functional and quantitative terms involved a process of systematisation in which 'areas of dispersed pluralism were displaced by a pluralism that was increasingly coordinated... Such a trend would not imply that the centre necessarily gets its own way, but only that the stakes are higher. There is the possibility of effecting extensive change, but there is also the possibility of meeting extensive opposition.' The policy process of introducing a unified system matches this description: conflicts are intensified, and central coordination increases. In our analysis, however, governance also becomes more top-down - centralised in McPherson and Raab's sense because participants become disenfranchised. A trend towards stronger corporatism may seem inevitable.

The fourth issue where our analysis echoes that of McPherson and Raab concerns the role of ideology and consensus. McPherson and Raab perceive a decline in the consensus which has traditionally sustained the policy community, partly reflecting the increased size and diversity of this community and of the issues with which it had to deal. They point to the development of universal certification, modularisation and flexible curricular structures as ways of escaping from the need for consensus on purposes and values. Purposes can be hidden behind an agreed if unspecified support for higher levels of attainment as measured by qualifications. And modularisation 'obviated the need for an explicit and public resolution of conflicting priorities. Modules were to make all things possible' (McPherson and Raab 1988, p.496). Higher Still similarly offered 'Opportunity for All'. At first sight a policy for flexibility may seem to avoid conflicts about purposes by allowing the education system to serve a variety of different purposes; only when the policy debate turned from the purposes of reform to the means of achieving those purposes did the conflicts become apparent. Postponing fundamental debates about values did not, in the end, make Higher Still's introduction easier to manage.

McPherson and Raab's analysis focuses on Scotland. We have linked the Scottish educational crissis of autumn 2000 to a policy which pursued flexibility of curriculum and student pathways as well as the unification of post-compulsory education. Yet other countries are pursuing policies for flexibility and unification (Lasonen and Young 1998, Green et al. 1999, OECD 2000). Further research is required to establish whether Scotland has merely anticipated a more global crisis of educational governance, or whether the Scottish crisis of 2000 reflects its distinctive political circumstances and its distinctive model of a flexible unified system.

Finally, and with respect to that model, at the beginning of this paper we asked 'what happened to the consensus on Higher Still?' Part of the answer is that it never went away. There is still wide support for the aims of Higher Still, if not for all of its changes (ECSC 2000a, MORI 2001, Tinklin et al. 2001). Given that the process of introducing a flexible unified system is inherently conflict-prone, the remarkable thing is not that Higher Still has 
attracted controversy, but that support for the reform has remained so strong. This may be a testimony to the strength of the initial consensus.

\section{ACKNOWLEDGEMENTS}

This paper is a product of the ESRC research project on Introducing a Unified System of Post-Compulsory Education in Scotland (IUS) (R000238420). It also draws on the earlier ESRC-funded Unified Learning Project. We are grateful to members of the IUS Advisory Committee for comments on an earlier draft: Janet Draper, John Fairley, Walter Humes, Jim Gallacher, Pamela Munn and Gillian Raab.

\section{REFERENCES}

Association of Directors of Education in Scotland, Association of Scottish Colleges and Her Majesty's Inspectors of Schools (ADES/ASC/HMI) (2001) National Investigation into the Experience of Higher Still Assessment in Schools and Colleges. (Edinburgh: HMI). http://www.scotland.gov.uk/hmis/Pdf/01_02/higher_still/higherstillreport.pdf.

Education, Culture and Sport Committee, Scottish Parliament (ECSC) (2000a) Exam Results Inquiry. Volume 1: Report. SP Paper 234 (Edinburgh: The Stationery Office) .

ECSC (2000b) Exam Results Inquiry. Volume 2: Evidence. SP Paper 234 (Edinburgh: The Stationery Office) .

Enterprise and Lifelong Learning Committee, Scottish Parliament (ELLC) (2000) Report on the Inquiry into the Governance of the Scottish Qualifications Authority (Edinburgh: The Stationery Office).

Fairley, J. and Paterson, L. (1995) Scottish education and the new managerialism, Scottish Educational Review, 27, 13-36.

Gray, J., McPherson, A. and Raffe, D. (1983) Reconstructions of Secondary Education (London: Routledge and Kegan Paul).

Green, A., Wolf, A. and Leney, T. (1999) Convergence and Divergence in European Education and Training Systems. Bedford Way Papers (University of London Institute of Education).

Higher Still Development Unit (1996a) Assessment (Edinburgh: HSDU).

HSDU (1996b) Responding to Consultation: principles for the post-16 curriculum and core skills (Edinburgh: HSDU).

Howieson, C., Croxford, L. and Raffe, D. (1990) After the Action: Young People's Reaction to the National Certificate (CES, University of Edinburgh).

Howieson, C. (1992) Modular Approaches to initial Vocational Education and Training: The Scottish Experience. A Report for the PETRA Research Programme 1991-93 (CES, University of Edinburgh).

Howieson, C., Raffe, D Spours, K. and Young, M., (1998) Group Awards and Over-Arching Certification and the Unification of Academic and Vocational Learning. ULP Working Paper 6 (Universities of Edinburgh and London). 
Humes, W. (1986) The Leadership Class in Scottish Education (Edinburgh: John Donald).

Humes, W. (1995) The significance of Michael Forsyth in Scottish education. Scottish Affairs, 11, 112-30.

Humes, W. (1998) Policy-making in Scottish education, in T. Bryce and W. Humes (eds), Scottish Education (Edinburgh: Edinburgh University Press).

Institute for Public Policy Research (IPPR) (1990) A British Baccalauréat? Ending the division between education and training (London: IPPR).

Lasonen, J. and Young, M. (eds) (1998) Strategies for Achieving Parity of Esteem in European Upper-Secondary Education (Institute for Educational Research, University of Jyväskylä).

McPherson, A. (1992) The Howie Report on post-compulsory schooling, in L. Paterson and D. McCrone (eds), Scottish Government Yearbook 1992 (Edinburgh: Unit for the Study of Government in Scotland).

McPherson, A. and Raab, C. (1988) Governing Education (Edinburgh: Edinburgh University Press).

MORI (2001) Higher Still - Internal Assessment: Report. Research Study conducted for the Educational Institute off Scotland and the Scottish Secondary Teachers' Association (Edinburgh: MORI).

National Commission on Education (1993) Learning to Succeed (London: Heinemann).

Organisation for Economic Cooperation and Development (2000) From Initial Education to Working Life: Making Transitions Work (Paris: OECD).

Paterson, L. (2000) Crisis in the Classroom: The exam debacle and the way ahead for Scottish education (Edinburgh: Mainstream).

Raffe, D. (1997) Upper-secondary education, in M. Clark and P. Munn (eds), Education in Scotland (London: Routledge).

Raffe, D. and Howieson, C. (1998) The Higher Still policy process. Scottish Affairs, 24, 90108.

Raffe, D., Howieson, C., Spours, K. and Young, M. (1998) The unification of postcompulsory education: Towards a conceptual framework, British Journal of Educational Studies, 46 (2), 169-187.

Scottish Association of Teachers of Language and Literature (SATOLL) (1999) Sense and Worth: Scottish education, the teaching of English and the Higher Still programme (Edinburgh: SATOLL).

Scottish Executive (2000) A Review into Exam Results Issues Concerning the Scottish Qualifications Authority. http://www.scotland.gov.uk/library3/education/sqar-01.asp. (Downloaded 13.11.00).

Scottish Executive (2001) Review of Initial Implementation of New National Qualifications. http://www.scotland.gov.uk/library3/education/nqir-01.asp. (Down-loaded 28.06.01). 
Scottish Further Education Unit and Higher Still Development Unit (SFEU/HSDU) (2000) Higher Still in Practice Survey Report: The first year of the new National Qualifications in FE (Stirling: SFEU).

Scottish Office (1994) Higher Still: Opportunity for All. Edinburgh.

Scottish Office Education Department (SOED) (1992) Upper Secondary Education in Scotland (Howie Report) (Edinburgh: HMSO).

Spours, K., Young, M., Howieson, C. and Raffe, D. (1998) Regulatory and Awarding Bodies and the Process of Unification in England and Scotland. ULP Working Paper 4 (Universities of Edinburgh and London).

Spours, K., Young, M., Howieson, C. and Raffe, D. (2000) Unifying academic and vocational learning in England, Wales and Scotland, in F. Coffield (ed.), Differing visions of a Learning Society. Research Findings Volume 1 (Bristol: Polity Press).

Tinklin, T., Howieson, C. and Raffe, D. (2001, forthcoming) How schools and colleges responded to Higher Still (provisional title) (CES, University of Edinburgh).

Young, M., Howieson, C., Raffe, D. and Spours, K. (1997) Unifying academic and vocational learning and the idea of a learning society. Journal of Education Policy, 12 (6), 527-537. 